\title{
EFFECTIVENESS OF CONSERVATION CROP ROTATION FOR WATER POLLUTANT REDUCTION FROM AGRICULTURAL AREAS
}

\author{
L. Koropeckyj-Cox, R. D. Christianson, Y. Yuan
}

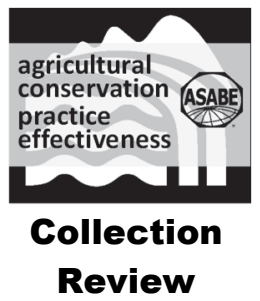

HighLights

- Adjusting nitrogen $(\mathrm{N})$ fertilization rates for corn following legumes can reduce $\mathrm{N}$ losses.

- Including perennial legumes in corn rotations can reduce nitrate-N losses and improve water quality.

- Crop rotations that include three or more years of legumes can be cost-effective.

- Corn-soybean was the most cost-effective, with a net benefit in nitrate-N loss reduction compared to continuous corn.

ABSTRACT. Legumes included in corn-based crop rotation systems provide a variety of benefits to the subsequent crops and potentially to the environment. This review aims to synthesize available data from the literature on legume $N$ credits and the effects of crop rotations on water quality, as well as to analyze the cost benefits associated with different legume-corn rotation systems. We found that there was much variation in reported values for legume $N$ credits to subsequent corn crops, from both empirical results and recommendations made by U.S. land grant universities. But despite inherent complexity, accounting for this contribution is critical when estimating optimal $N$ fertilizer application rates as part of nutrient management. Results from research on the influence of crop rotations on water quality show that including legumes in cornbased rotation systems generally decreases nitrate- $N$ concentrations in subsurface drainage discharge. Our cost analysis showed that incorporating legumes in cropping systems reduced $N$ fertilizer and pesticide costs compared to conventional cropping systems, i.e., continuous corn and corn-soybean rotations, but extended rotations, such as corn-soybean-alfalfaalfalfa-alfalfa, are not as profitable as conventional systems in the U.S. Midwest. In comparing continuous corn and cornsoybean rotations, although their impacts on water quality are not significantly different when using overall means from the literature data, corn-soybean rotations are more profitable than continuous corn. When using data from papers that directly compared the two, we found that switching from continuous corn to corn-soybean can provide a benefit of \$5 per $\mathrm{kg} N$ loss reduction. The cost analysis methods used could be tailored to any location or management scenario with appropriate inputs and serve as a useful tool for assessing cost benefits for other agricultural conservation practices. Legumecorn crop rotations have the potential to be an effective conservation practice with the ultimate goal of improving water quality, and, with further research, these rotations could be made even more effective by integrating them into a multipractice system.

Keywords. Conservation practice, Cost analysis, Crop rotation, Nitrate, Nutrient management, Water quality.

Submitted for review in March 2020 as manuscript number NRES 14017; approved for publication as an Invited Review Article and as part of the Agricultural Conservation Practice Effectiveness Collection by the Natural Resources \& Environmental Systems Community of ASABE on 19 June 2020.

Mention of company or trade names is for description only and does not imply endorsement by the USEPA. The USEPA is an equal opportunity provider and employer.

The authors are Lydia Koropeckyj-Cox, ORISE Research Participant, U.S. Environmental Protection Agency, Research Triangle Park, North Carolina; Reid D. Christianson, Assistant Professor, Department of Crop Sciences, University of Illinois, Urbana, Illinois; Yongping Yuan, Research Hydrologist, U.S. Environmental Protection Agency, Research Triangle Park, North Carolina. Corresponding author: Yongping Yuan, U.S. EPA, 109 T.W. Alexander Dr., Research Triangle Park, NC 27711; phone: 919-541-2036; e-mail: yuan.yongping@epa.gov.
$\mathrm{T}$ his article is part of a collection that provides a systematic review and evaluation of the performance and cost-effectiveness of select agricultural conservation practices (ACPs) on nutrient and sediment loss reduction.

Conservation crop rotation (NRCS Code 328) is a practice that consists of growing a series of crops in the same field over a given rotation cycle or period of time (USDA-NRCS, 2015). Conservation crop rotation (crop rotation, for simplicity) can be one part of nutrient management (NRCS Code 590) systems when nitrogen (N)-fixing legumes are included (USDANRCS, 2013). In N fertilizer recommendations, the recommended application rate of $\mathrm{N}$ fertilizer may be adjusted for the given agricultural conditions, e.g., when legumes are grown prior to other crops such as corn. These fertilizer recommendations attempt to address the discrepancy between the 
amount of $\mathrm{N}$ provided by the soil and the amount needed by crops as closely as possible to reduce excess fertilizer applications and minimize nutrient losses from agricultural fields.

For corn (Zea mays [L.]), $\mathrm{N}$ fertilizer application rate recommendations can be estimated based on corn grain yields or on economic returns and can include credits to account for other sources of $\mathrm{N}$, which ultimately reduce the overall amount of fertilizer that must be applied (Morris et al., 2018; Stanford, 1973). Some of these N credits are based on planting corn in rotation with legumes, e.g., soybeans (Glycine $\max$ [L.] Merr.) or alfalfa (Medicago sativa [L.]), because legumes can aid in the process of atmospheric $\mathrm{N}_{2}$ fixation and mineralization of $\mathrm{N}$ in soils (fig. 1) (Heichel, 1987a; Vanotti and Bundy, 1995; Gentry et al., 2001). This practice of growing legume crops in rotation with corn can reduce the amount of $\mathrm{N}$ that must be applied to the subsequent corn crop, as well as reduce the amount of $\mathrm{N}$ available for environmental loss, which can potentially improve water quality.

Numerous peer-reviewed research articles and land grant university (LGU) cooperative extension service publications have documented the amount of $\mathrm{N}$ contributed by different legumes in rotation with corn. Studies have also assessed the various other benefits provided by legume-corn crop rotations. Besides their contribution of $\mathrm{N}$ to subsequent crops, including legumes in rotation systems can increase corn yields (Attia et al., 2015; Liebman et al., 2008; Ma et al., 2003; Omay et al., 1998; Peterson and Varvel, 1989; Schepers et al., 1995; Singer and Cox, 1998), mitigate the yield penalty of continuous corn cropping (Crookston et al., 1991; Gentry et al., 2013a; Seifert et al., 2017), improve soil tilth (Karlen et al., 2006; Lal et al., 1994; N'Dayegamiye et al., 2015), break cycles of disease (Baumhardt and Anderson, 2006; Bullock, 1992; Reid et al., 2001; Maloney et al., 1999), control the growth of weeds (Goplen et al., 2018; Liebman et al., 2008), increase soil organic matter content (Havlin et al., 1990; Karlen et al., 2006; Yusuf et al., 2009), and improve water quality by reducing nitrate losses (Fox et al., 2001; Kanwar et al., 2005; King et al., 2016; Owens, 1990; Owens et al., 2000; Randall et al., 1997; Shipitalo et al., 2013).

In the U.S., extended rotations are generally less widely practiced than shorter rotations. A two-year annual corn-soybean rotation is the most commonly implemented rotation

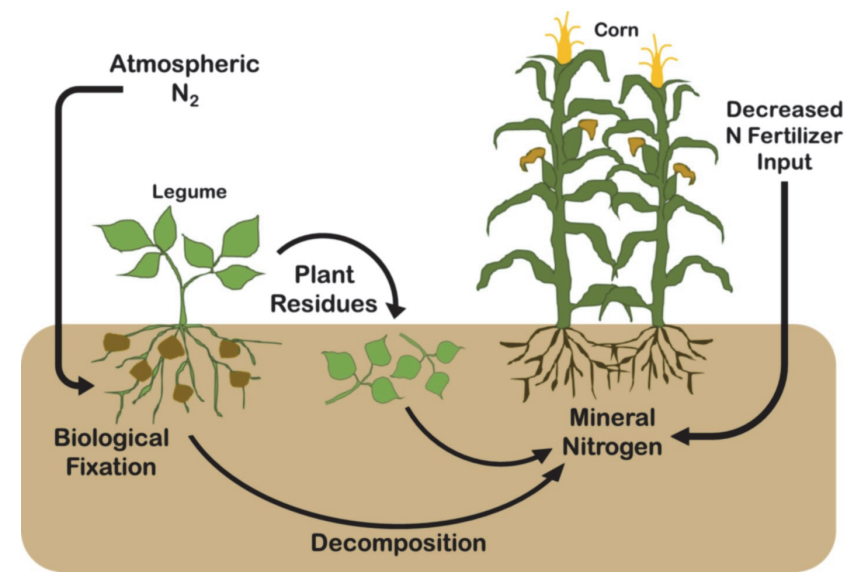

Figure 1. Conceptual diagram of the nitrogen $(N)$ cycle in agricultural soils as it pertains to crop rotations and the $N$ benefits of legumes planted in rotation with corn (adapted from NC State University). system in the U.S. Corn Belt, a region in the Midwest consisting of mainly the states of Illinois, Indiana, Iowa, Minnesota, Nebraska, Ohio, South Dakota, and Wisconsin that produces much of the nation's corn (Green et al., 2018); 83\% of agricultural land in these states was planted to corn and soybean in 2010 (USDA-NASS, 2010). In Iowa alone, a 2014 survey found that $80 \%$ of farmers polled practice this annual corn-soybean rotation, while only about $19 \%$ include a third crop in their rotation systems (Mine et al., 2014). Additionally, the Iowa Farm and Rural Life Poll reported that just $22 \%$ of farmers surveyed used an extended crop rotation system in 2018 (ISU, 2019a).

The U.S. Corn Belt, especially intensive corn-soybean production, is also a large contributor to nutrient loading in the Mississippi River basin and subsequent eutrophication of the Gulf of Mexico (David et al., 2010; Piske and Peterson, 2020; Saad and Robertson, 2020), with Iowa contributing on average $45 \%$ of the nitrate load in the upper Mississippi River basin (Jones et al., 2018). Due to the prevalence of corn-based cropping systems in the Corn Belt, a key region of the U.S. in terms of agriculture and water quality, this review is focused on corn-based crop rotations. Additionally, this review centers on the inclusion of legumes in corn-based rotations due to their benefits in terms of yield increases, savings on $\mathrm{N}$ fertilizer, and potential to improve water quality.

The overall objective of this article is to develop a systematic understanding of the effectiveness of crop rotation as a practice of nutrient management for water quality improvement. More detailed objectives are: (1) to compare, integrate, and synthesize results from peer-reviewed studies conducted under different experimental settings and site conditions on legume N credits to corn; (2) to synthesize available information on legume-corn crop rotations and water quality to better understand how these types of rotations can improve water quality; (3) to perform a cost analysis for various corn-based crop rotations, including extended rotation systems, to obtain general insights on performance-based costs associated with implementing this conservation practice. Information gained from this review can be used for the following purposes: (1) to help inform the selection of legumes and rotation patterns for $\mathrm{N}$ management in corn cropping systems for water quality improvement; (2) to develop recommendations for cost-effective conservation practices to be considered for prioritization when funding agencies are developing their programs; (3) to support and update the technical content in the USDA Natural Resources Conservation Service (USDA-NRCS) conservation practice standards, as well as help agencies and organizations document the magnitude of the nutrient pollution reduction efforts in an area of interest. A summary of the findings of this review is presented in the Appendix (https://doi.org/10.13031/13924703.v1).

\section{Nitrogen CREDITS FOR VARIOUS CROP ROTATION SYSTEMS}

Accounting for the $\mathrm{N}$ contributed by legumes in crop rotations with corn is one way to practice nutrient management. Subtracting legume N credits from the overall recommended fertilizer $\mathrm{N}$ application rate reduces the amount of 
excess fertilizer $\mathrm{N}$ in the system, which can prevent surplus $\mathrm{N}$ balances and subsequent nutrient pollution from surface runoff and subsurface drainage from agricultural fields (Blesh and Drinkwater, 2013; Daryanto et al., 2017; ISU, 2017). The magnitude of $\mathrm{N}$ credits may vary based on factors such as crop type, climate, soil characteristics, and the other management practices in place, but it is important to account for legume $\mathrm{N}$ contributions in crop rotations so that the optimal fertilizer rate may be applied.

A search of the available literature was performed to gather information from relevant peer-reviewed research articles that studied the $\mathrm{N}$ contribution of legumes to corn in different crop rotation systems. Our literature search was conducted from late 2019 through early 2020, and the following keywords were used as search inputs for Google Scholar, JSTOR, PubMed, Web of Science, and Science Direct: legume, $\mathrm{N}$ credit, corn/maize, and crop rotation. The scope was limited to empirical field studies conducted in North America. Modeling studies, laboratory experiments, and review papers were not included in our literature pool. Furthermore, the selected articles must have been peer-reviewed, published in English between 1980 and 2019, and must explicitly estimate and report a $\mathrm{N}$ credit value for the crops under study. While we did not include international studies in our synthesis of $\mathrm{N}$ credit experiments, some pertinent results are used as examples in the text.

A search of relevant available university extension service publications was also performed to compare experimental $\mathrm{N}$ credit data to official LGU recommendations. This was done by searching the individual online publication databases of U.S. LGU cooperative extension services for fertilizer $\mathrm{N}$ recommendations for corn and specific legume $\mathrm{N}$ credits via each university extension's website homepage. A total of $34 \mathrm{LGU}$ publications were found, representing 34 states. Some of these publications were in the form of brief fact sheets that reported legume $\mathrm{N}$ credits as part of fertilizer recommendations for corn. The reports we found were pub- lished or revised between 1995 and 2019, and the legume N credits from these reports were based on each university's specific estimation method and data from on-farm studies.

These data gathered from research articles and LGU extension publications on legume $\mathrm{N}$ credits to corn were compiled for each species of legume crop for which data were available, and ranges, medians, and quartiles were determined. For research articles and LGU publications that presented a range of values for one legume crop depending on stand quality or yield, the listed increments within that range were included as individual data points or, if none were listed, the minimum and maximum of the range were used. Some LGUs did not have a recommended $\mathrm{N}$ credit to corn for certain legume crops and were not included in the dataset, but those that reported a 0 value $\mathrm{N}$ credit were included. Legume $\mathrm{N}$ credit values of 0 indicate that the amount of fertilizer applied to succeeding corn crops should not be reduced to account for the preceding legumes, whereas negative $\mathrm{N}$ credit values (e.g., from Bundy et al., 1993) theoretically represent legumes altering the growing conditions in such a way that more fertilizer must be applied to the subsequent corn crop rather than less. A summary of the reviewed literature can be found in tables A1 and A2 in the Appendix.

The soybean $\mathrm{N}$ credits recommended by the sampled LGUs ranged from 0 to $50 \mathrm{~kg} \mathrm{~N}^{-1}$, while those determined empirically ranged from -22 to $210 \mathrm{~kg} \mathrm{~N} \mathrm{ha}^{-1}$ (fig. 2). The LGU-recommended alfalfa $\mathrm{N}$ credits ranged from 0 to 213 $\mathrm{kg} \mathrm{N} \mathrm{ha}^{-1}$, while those from experimental data ranged from 8 to $305 \mathrm{~kg} \mathrm{~N} \mathrm{ha}^{-1}$. There were much fewer data regarding $\mathrm{N}$ credits of other legumes. The $\mathrm{N}$ credit values for field pea (Pisum sativum) ranged from 22 to $56 \mathrm{~kg} \mathrm{~N} \mathrm{ha}^{-1}$ for the LGU recommendations and from 8 to $26 \mathrm{~kg} \mathrm{~N} \mathrm{ha}^{-1}$ for empirical studies. The LGU recommendations for peanut (Arachis hypogaea) $\mathrm{N}$ credits ranged from 22 to $50 \mathrm{~kg} \mathrm{~N} \mathrm{ha}^{-1}$, but we did not find any North American studies that reported a peanut $\mathrm{N}$ credit. However, Ennin et al. (2004) determined the peanut $\mathrm{N}$ credit to corn to be 0 for their site conditions in Ghana,

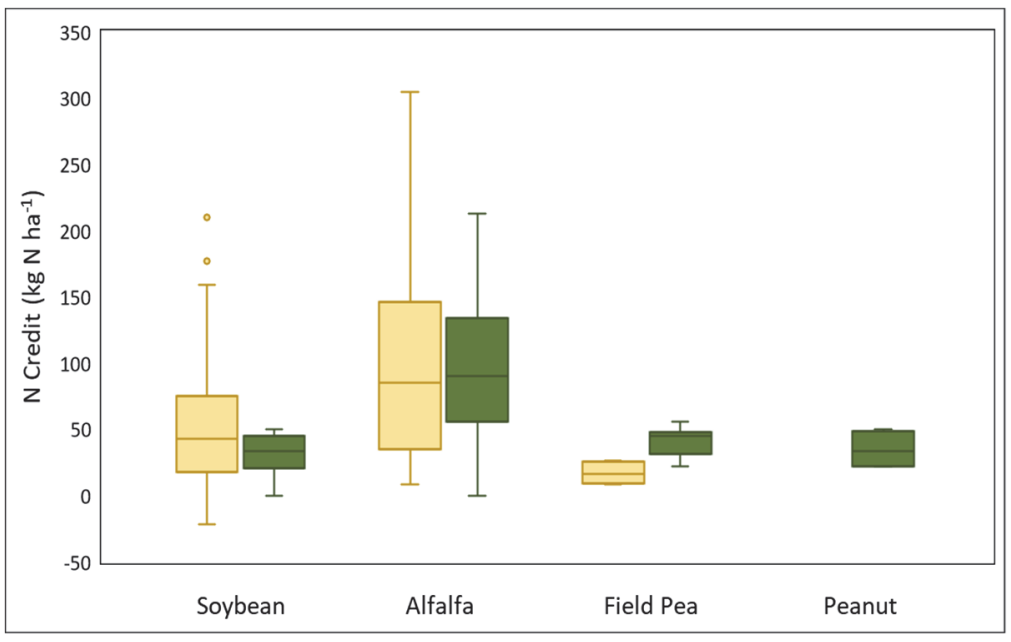

Figure 2. Box plots showing the reported legume $\mathbf{N}$ credits recommended by U.S. land grant university cooperative extension services (green, right) and determined empirically by peer-reviewed studies (yellow, left). The 10th percentile is represented by the lower whisker, the 25 th percentile is represented by the bottom of the box, the median is represented by the line in the middle of the box, the 75th percentile is represented by the top of the box, and the 90th percentile is represented by the top whisker. There were 23 universities with soybean $\mathrm{N}$ credits, 26 with alfalfa credits, 6 with field pea credits, and 3 with peanut credits (34 universities were included, representing 34 states). There were 18 studies that reported soybean $\mathrm{N}$ credits, 12 that reported alfalfa credits, 2 that reported field pea credits, and 0 that reported a peanut $\mathrm{N}$ credit (results from 27 studies were included in the dataset, across 11 U.S. states and 3 Canadian provinces). 
and Bloem and Barnard (2001) found the "nitrogen advantage" of peanut to corn to be about $7 \mathrm{~kg} \mathrm{~N} \mathrm{ha}^{-1}$ at their research sites in South Africa. Overall median values were similar between the articles and LGU publications within soybean and alfalfa $\mathrm{N}$ credit datasets. Median soybean $\mathrm{N}$ credits were 43 and $34 \mathrm{~kg} \mathrm{~N} \mathrm{ha}^{-1}$ for the experimental data ( $n$ $=120)$ and the LGU recommendations $(n=30)$, respectively, and median alfalfa $\mathrm{N}$ credits were $85(n=32)$ and $90(n=$ 77) $\mathrm{kg} \mathrm{N} \mathrm{ha}^{-1}$, respectively. However, it is likely that some of the LGU values could have been partly based on the results of one or more of the empirical studies included in the analysis.

Variation in the values from the empirical data likely resulted from characteristics of the study site, the other agricultural practices in place, and the estimation method used. Among the studies reviewed here, various methods were used to calculate resulting legume $\mathrm{N}$ credits, but the two most common were the so-called traditional method and the difference method (table A1). The traditional method of estimating a $\mathrm{N}$ fertilizer replacement value (NFRV or FRV) of legumes to subsequent corn crops involves determining the amount of $\mathrm{N}$ fertilizer needed by corn in a monocropped system to achieve the same yield as corn planted following a legume crop when no $\mathrm{N}$ fertilizer is applied (Hesterman et al., 1987; Reeves, 1994; Shrader et al., 1966). The difference method involves measuring the fertilizer $\mathrm{N}$ response in succeeding corn crops independently for each crop sequence under many different fertilizer application rates (Lory et al., 1995; Reeves, 1994; Smith et al., 1987). The difference method can be seen as producing a more accurate estimate of legume $\mathrm{N}$ contributions because it does not rely on the assumption that subsequent corn crops will have the same response to $\mathrm{N}$ fertilizer regardless of the preceding crop (Lory et al., 1995; Reeves, 1994; Smith et al., 1987). The difference approach is also not compounded by non-N rotation effects, which cannot be directly replaced by any amount of $\mathrm{N}$ fertilizer.

Each U.S. LGU extension service may have a unique method for estimating legume $\mathrm{N}$ credits for use in $\mathrm{N}$ fertilizer rate recommendations, which may explain much of the variation in $\mathrm{N}$ credit values reported by the LGUs cited here. For example, Pennsylvania and Virginia use the yield of the previous legume crop to calculate its corresponding $\mathrm{N}$ credit for corn (Alley et al., 2009; Beegle, 2015). New York and South Dakota vary the legume crop's N credit based on the number of years following its cultivation in a rotation sequence with corn (Ketterings et al., 2003; Reitsma et al., 2016).

The effects of legume-corn crop rotations on soil and growing conditions are diverse, so they are generally separated into $\mathrm{N}$ and non-N "rotation effects" (Bullock, 1992; Crookston and Kurle, 1989; Hesterman et al., 1987). The legume $\mathrm{N}$ credit in fertilizer $\mathrm{N}$ rate recommendations is mainly based on the amount of $\mathrm{N}$ that legumes grown prior to corn may contribute to following crops (Gentry et al., 2001; Morris et al., 2018; Nafziger et al., 2004; Smith et al., 1987). This $\mathrm{N}$ contribution primarily comes from the symbiotic relationship between the legume plants and rhizobia in root nodules, which fixes $\mathrm{N}_{2}$ from the atmosphere and converts it into a form usable by plants (Heichel, 1987a; Vanotti and Bundy, 1995; Gentry et al., 2001). Nitrogen that is taken up and immobilized in legume plant tissues can then be transferred to following crops when residues (stems, foliage, and roots) left in the soil decompose and mineralize (Heichel, 1987a). Rotating other crops with legumes can also increase the $\mathrm{N}$ fertilizer yield response in the following crops as well as those plants' $\mathrm{N}$ use efficiency (NUE) (Hesterman et al., 1987; Peterson and Varvel, 1989; Attia et al., 2015). Generally, corn planted after legumes produces higher grain yields and exhibits increased aboveground $\mathrm{N}$ uptake compared to continuous corn, mainly due to this $\mathrm{N}$ contribution (Crookston et al., 1991; Gentry et al., 2001; Hesterman et al., 1987; Hesterman et al., 1986; Schepers et al., 1995).

Climatic and soil conditions of the study area or LGU location may also contribute in large part to the variation seen in the legume $\mathrm{N}$ credit values (fig. 2). Studies have found that climate (De Haan et al., 2017; Francis and Schepers, 1989; Lawlor et al., 2008; Randall and Sawyer, 2008; Randall and Mulla, 2001), soil physical and chemical characteristics (Wolkowski et al., 1998), crop type or cultivar (Ashworth et al., 2016; Crookston et al., 1991; Harris and Hesterman, 1990; Kelner et al., 1997; Meese et al., 1991; Yost et al., 2012), and different farm management practices (Coulter and Nafziger, 2008; Klocke et al., 1999; Lund et al., 1993; Meese et al., 1991; Schepers et al., 1995; Yost et al., 2012; Rembon and MacKenzie, 1997) may affect the amount of $\mathrm{N}$ that legume crops can contribute to subsequent corn crops.

In humid regions, where precipitation rates are high or soils are not well-drained, some of the $\mathrm{N}$ contributed by a legume crop may be lost by denitrification, leaching into underlying groundwater, or surface runoff (De Haan et al., 2017; Francis and Schepers, 1989; Hesterman et al., 1986; Lawlor et al., 2008; Randall and Sawyer, 2008; Randall and Mulla, 2001). Soils that are well-drained, such as sandy or coarse-textured soils, are more likely to lose $\mathrm{N}$ to leaching (Wolkowski et al., 1998), so more $\mathrm{N}$ fertilizer must be applied to compensate for this effect and maintain yields, and legume $\mathrm{N}$ credits may be reduced in this case. The rate and timing of irrigation can also affect the amount of $\mathrm{N}$ lost to leaching (Klocke et al., 1999; Schepers et al., 1995). These factors need to be considered when adjusting the application rate of $\mathrm{N}$ fertilizer to account for potential losses.

How producers harvest or plow the preceding legume crop in a legume-corn rotation also matters (Heichel, 1987b; Kanwar et al., 1997; Lund et al., 1993; Meese et al., 1991; Weed and Kanwar, 1996; Yost et al., 2012). For example, harvesting only some parts of the preceding legume crop, plowing and leaving the plant material to decompose, or employing a no-till system can preserve the $\mathrm{N}$ contributed by the legumes in the field and provide other benefits, such as preventing soil erosion (Ashworth et al., 2016; Coulter and Nafziger, 2008; Heichel, 1987b; Lund et al., 1993; Meese et al., 1991; Yost et al., 2012).

The type of legume chosen for a rotation sequence with corn, as well as the length of time of the rotation period, can have a significant impact on the amount of $\mathrm{N}$ contributed by legumes to the following corn crop (Ashworth et al., 2016; Crookston et al., 1991; Frankenberger and Abdelmagid, 1985; Kelner et al., 1997; Meese et al., 1991; Yost et al., 
2012). Each type of legume, whether soybean, alfalfa, peanut, or pea (and their different cultivars) can be more or less effective at fixing and providing $\mathrm{N}$ to the succeeding crop. For example, Frankenberger and Abdelmagid (1985) found that more $\mathrm{N}$ was mineralized from soybean (Glycine max [L.] Merr.) and clover (Trifolium alexandrinum Fahl.) residues than from alfalfa (Medicago sativa [L.]) and cowpea (Vigna unguiculata [L.] Walp.) residues over the same period. The main reason for this is due to differences in the chemical makeup of crop biomass, namely the ratio of carbon (C) to nitrogen in different crop species and plant materials (Frankenberger and Abdelmagid, 1985; Harris and Hesterman, 1990; Heichel, 1987b; Kelner et al., 1997; Meese et al., 1991), which indicates how quickly the biomass will likely degrade and release N. The type and cultivar of legume crop, inoculation with rhizobia, and presence and number of root nodules may also play a role in the amount of $\mathrm{N}$ contributed by a legume to the following crop (Alvey et al., 2003; Bagayoko et al., 2000; Frankenberger and Abdelmagid, 1985; Meese et al., 1991; Mulvaney et al., 2017; Russelle et al., 1994).

Additionally, corn plants are limited in how efficiently they can take up and use $\mathrm{N}$ in the soil (Harris and Hesterman, 1990; Power et al., 1986; Yost et al., 2012). Some fertilizer recommendation systems are based on an average $\mathrm{N}$ uptake by corn of about $35 \%$ to $75 \%$ of plant-available soil N (Cassman et al., 2002; Ketterings et al., 2003; Meisinger, 1984; Stanford, 1973). Other studies have found that the recovery of $\mathrm{N}$ in corn grains can be anywhere from $13 \%$ to $45 \%$, and the amount left unrecovered in the soil may range from $23 \%$ to $64 \%$ (Harris and Hesterman, 1990; Kitur et al., 1984; Olson, 1980; Sanchez and Blackmer, 1988; Varvel and Peterson, 1990). While there is some evidence supporting the ability of corn plants to use organic sources of N (Grantham, 2015), organic $\mathrm{N}$ may not be used as efficiently as inorganic $\mathrm{N}$ in the forms commonly used for commercial fertilizers (Hesterman et al., 1987) and would be a relatively small component, as approximately $99 \%$ of $\mathrm{N}$ enters the plant in the form of nitrate $\left(\mathrm{NO}_{3}\right)$ through mass flow with water (Havlin et al., 2014).

The compounding factors enumerated above will necessarily impact the amount of $\mathrm{N}$ contributed by legume crops in rotation with corn, and as a result, these factors will influence the magnitude of the legume $\mathrm{N}$ credit for a given crop, location, or production system. Therefore, these factors should be taken into account as much as possible when considering which crop rotation sequence to implement in order to maximize the conservation and production benefits.

Given the complexity summed up in the simple term "rotation effects," legume $\mathrm{N}$ credits can be difficult to measure and assign on a field-by-field basis and may not completely capture the range of benefits provided by legumes in rotation with other crops. As more research is done on the processes that govern legume $\mathrm{N}$ contributions in crop rotations, more uncertainty is introduced regarding the practicality of $\mathrm{N}$ credits as a concept. While it may be impossible to devise a perfect system for providing fertilizer $\mathrm{N}$ rate recommendations, it is still useful to account for site-specific conditions and agricultural practices like crop rotation when determining the optimal rate of $\mathrm{N}$ fertilizer to apply. Furthermore, yield-based approaches and $\mathrm{N}$ crediting often seem more common-sense to producers, and thus more accessible, than simulation models or lab analyses of soil and plant samples (Morris et al., 2018). Therefore, attempting to quantify legume $\mathrm{N}$ contributions is valuable in the effort to reduce nutrient losses and subsequent water pollution.

\section{WATER QUALITY BENEFITS FROM VARIOUS CROP ROTATION SYSTEMS}

In addition to the $\mathrm{N}$ benefit contributed by legumes to following corn crops, including legumes in extended crop rotation systems can impact surface and subsurface water quality. Generally, crop rotation systems that include legumes have been found to reduce nitrate losses compared to cereal monocultures, such as continuous corn (Fox et al., 2001; Kanwar et al., 2005; King et al., 2016; Owens, 1990; Owens et al., 2000; Randall et al., 1997; Shipitalo et al., 2013). The low C: $\mathrm{N}$ ratio of legume residues promotes net $\mathrm{N}$ mineralization in the soil, allowing the $\mathrm{N}$ immobilized in legume residues to be converted to plant-available forms more slowly compared to the inorganic $\mathrm{N}$ found in synthetic commercial fertilizers (Frankenberger and Abdelmagid, 1985; Harris and Hesterman, 1990; Heichel, 1987b; Kelner et al., 1997). This fact, combined with a reduction in the amount of $\mathrm{N}$ fertilizer that needs to be applied over the whole legume-corn crop rotation period, can reduce nitrate losses to surface and subsurface water resources (ISU, 2017).

A literature search was performed to gather relevant research articles that studied the effects of different crop rotations on water quality. Our literature search was conducted from late 2019 through early 2020, and the following keywords were used as search inputs for Google Scholar, JSTOR, PubMed, Web of Science, and Science Direct: crop rotation, legume, water quality, corn/maize, runoff, and subsurface drainage. The scope was limited to field studies conducted in North America, so modeling studies, laboratory experiments, and review papers were not included in our literature pool. This was done to limit the scope to studies that empirically determined nutrient losses so that the results synthesized here reflect real patterns observed in the field rather than in the lab or through model simulations. Furthermore, the selected articles must have been peer-reviewed, published in English between 1980 and 2019, and must report nutrient concentrations, losses, or both for each crop studied or over whole rotations.

The studies found through our literature search encompassed sites across the U.S. and Canada and mainly involved implementing different crop rotation systems, applying fertilizer at varying rates, and measuring the chemical contents and amount of subsurface drainage discharge and/or surface runoff for each crop in the rotation or for whole rotations (tables A3 through A7 in the Appendix). Some studies also incorporated other management practices in their evaluations by varying tillage practices and fertilizer type by treatment (e.g., Shipitalo et al., 2013; Weed and Kanwar, 1996; El-Hout and Blackmer, 1990; Woodley et al., 2018). Measurements of drainage or runoff amount and contents were then used by the researchers to evaluate the effectiveness of 
certain cropping systems in reducing nitrate losses from agricultural fields. Some of the studies also measured other losses, such as dissolved P or sediments, but this review mainly focuses on the influence of crop rotation on nitrate loss because that nutrient had the most data available. In the process of data extraction from the literature, losses were defined as the reported nutrient loss from each study year or the annual average of the study period for each crop or cropping system under study. A summary of this literature search can be found in tables A3 through A7 in the Appendix.

In general, extended crop rotations, especially those that included legumes, were more effective in preventing $\mathrm{N}$ losses than conventional cropping systems, such as continuous corn or annual corn-soybean rotations (fig. 3) (Blesh and Drinkwater, 2013; Drinkwater et al., 1998; Kanwar et al., 2005; Randall et al., 1997; Shipitalo et al., 2013). The mean subsurface nitrate-N loss for continuous corn was $31.3 \mathrm{~kg} \mathrm{~N}$ ha $^{-1}(n=38, \mathrm{SD}=26.8)$, the mean for corn-soybean was 32.4 $\mathrm{kg} \mathrm{N} \mathrm{ha}^{-1}(n=85, \mathrm{SD}=23.2)$, the mean for corn-soybeanwheat was $12.2 \mathrm{~kg} \mathrm{~N} \mathrm{ha}^{-1}(n=12, \mathrm{SD}=9.2)$, the mean for continuous alfalfa was $22.3 \mathrm{~kg} \mathrm{Nha}^{-1}(n=6, \mathrm{SD}=20.2)$, and the mean for corn-oat-alfalfa-alfalfa was $13.4 \mathrm{~kg} \mathrm{~N} \mathrm{ha}^{-1}(n=$ $64, \mathrm{SD}=13.1$ ) (a mean is not given for alfalfa-alfalfa-alfalfacorn-soybean-oat because there was only one data point for this rotation).

In addition, the data from the literature indicated that the loss of nitrate- $\mathrm{N}$ in subsurface drainage discharge was greater for corn than during periods when fields were planted to other crops (fig. 4). The mean nitrate loss in subsurface discharge for corn years was $30.1 \mathrm{~kg} \mathrm{~N} \mathrm{ha}^{-1}(n=97$, $\mathrm{SD}=25.5)$, the mean for soybean was $28.9 \mathrm{~kg} \mathrm{~N} \mathrm{ha}^{-1}(n=$ $37, \mathrm{SD}=22.4)$, the mean for alfalfa was $13.6 \mathrm{~kg} \mathrm{~N} \mathrm{ha}^{-1}(n=$ $38, \mathrm{SD}=15.0)$, the mean for wheat was $12.3 \mathrm{~kg} \mathrm{~N} \mathrm{ha}^{-1}(n=$ $4, \mathrm{SD}=6.8)$, and the mean for oat was $6.3 \mathrm{~kg} \mathrm{~N} \mathrm{ha}^{-1}(n=$ $16, \mathrm{SD}=4.2$ ).

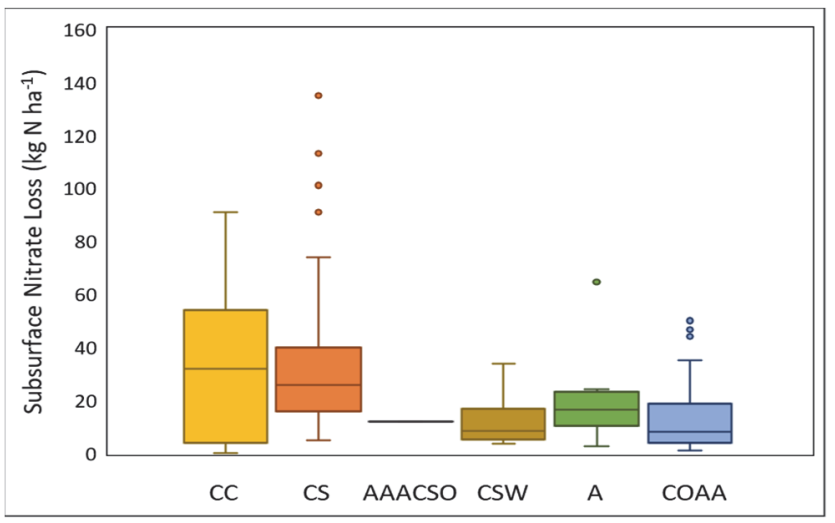

Figure 3. Box plots showing the reported data from the literature on the effects of crop rotation on water quality, specifically for subsurface nitrate- $\mathrm{N}$ losses. The 10th percentile is represented by the lower whisker, the 25th percentile is represented by the bottom of the box, the median is represented by the line in the middle of the box, the 75th percentile is represented by the top of the box, and the 90th percentile is represented by the top whisker. Cropping systems are labeled with crops in the order in which they appear in the rotation $(\mathrm{C}=$ corn $(Z e a$ mays [L.]), S = soybean (Glycine $\max [\mathrm{L}$.$] Merr.), A = alfalfa (Medicago$ sativa [L.]), $\mathrm{W}=$ winter wheat $($ Triticum aestivum $[\mathrm{L}]$.$) , and \mathrm{O}=$ oat (Avena sativa [L.]). There were 12 studies that reported nitrate losses for CC, 16 for CS, 1 for AAACSO, 1 for CSW, 4 for A (continuous alfalfa), and 2 for COAA.
There was much variation in the findings among the studies we reviewed. Kanwar et al. (2005) measured a 50\% reduction in flow-weighted nitrate concentrations in subsurface drainage water for an extended rotation (three years of alfalfa followed by corn, then soybean, then oats) compared to a conventional corn-soybean rotation (6.4 vs. $12.0 \mathrm{mg} \mathrm{L}-1)$. The Iowa Nutrient Reduction Strategy (ISU, 2017) reported a $42 \%$ reduction in nitrate-N loss for a corn-soybean-alfalfa-alfalfaalfalfa rotation compared to conventional cropping systems from their literature review. De Haan et al. (2017) found that this effect is partly due to a reduction in residual soil nitrate content, whereas Blesh and Drinkwater (2013) suggested that a reduction in overall $\mathrm{N}$ balance surpluses could also contribute to the reduction in field-scale nitrate losses. The results of a meta-analysis conducted by Daryanto et al. (2017) led those researchers to suggest that reducing $\mathrm{N}$ fertilizer application rates could also help curtail nitrate losses.

It should be noted that the nitrate losses measured in these studies were found to occur mainly in the off-season rather than during the growing season for annual crops (Bakhsh et al., 2007; King et al., 2016; Olsen et al., 1970; Owens, 1990; Owens et al., 2000; Syswerda et al., 2012). These off-season losses due to a lack of actively growing soil cover could potentially be mitigated by cultivating cover crops, especially legume varieties, during the winter off-seasons between annual summer cash crops (Strock et al., 2004; Askegaard et al., 2011; De Notaris et al., 2018; Abdalla et al., 2019). Cover crops could also be included as one of the crops in a rotation system and may be advantageous when used as pasture for production systems that include livestock. Implementing an integrated nutrient management system that incorporates a combination of legume rotations, appropriate fertilizer application rates, cover crops, and other conservation practices may be more effective in preventing nitrate losses and improving water quality compared to any stand-alone practice.

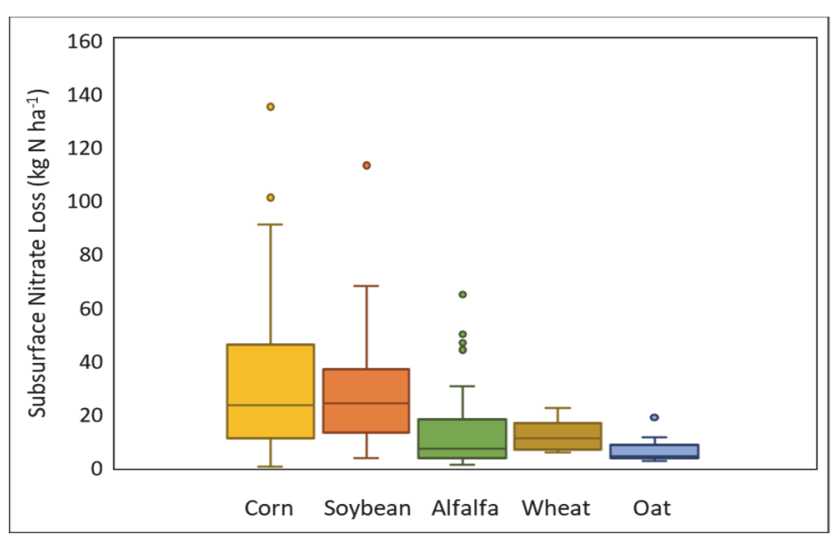

Figure 4. Box plots showing the reported data from the literature on the effects of crops within a rotation on water quality, specifically for subsurface nitrate- $\mathrm{N}$ losses. The 10th percentile is represented by the lower whisker, the 25th percentile is represented by the bottom of the box, the median is represented by the line in the middle of the box, the 75th percentile is represented by the top of the box, and the 90th percentile is represented by the top whisker $(\mathrm{C}=\operatorname{corn}($ Zea mays $[\mathrm{L}]),. \mathrm{S}=$ soybean (Glycine max [L.] Merr.), $A=$ alfalfa (Medicago sativa [L.]), $\mathrm{W}=$ winter wheat $($ Triticum aestivum $[\mathrm{L}]$.$) , and \mathrm{O}=\mathrm{oat}($ Avena sativa [L.]). There were 21 studies that reported nitrate losses for $\mathrm{C}, 12$ for $\mathrm{S}$, 6 for $A, 1$ for $W$, and 2 for $O$, for each crop either independently or within a larger rotation system. 
All of the factors that may influence the amount of $\mathrm{N}$ contributed by different legumes to subsequent crops can also impact the magnitude of nitrate losses in legume-corn crop rotation systems. In particular, precipitation (Klocke et al., 1999; Lawlor et al., 2008; Owens et al., 2000), soil characteristics (Wolkowski et al., 1998), and the other agricultural management practices in place, such as irrigation (Klocke et al., 1999), tillage (Daryanto et al., 2017; Drinkwater et al., 2000; Kanwar et al., 1997; Rekha et al., 2011; Shipitalo et al., 2013; Weed and Kanwar, 1996), and different nutrient management strategies (Drinkwater et al., 1998; El-Hout and Blackmer, 1990; Fox et al., 2001; King et al., 2016; Lawlor et al., 2008; Owens et al., 2000; Rekha et al., 2011; Zhu and Fox, 2003; Woodley et al., 2018), can have a significant impact on the amount of $\mathrm{N}$ available for loss via leaching or runoff.

In addition to reducing the amount of nitrate lost from agricultural fields, including legume crops in rotation systems can have other water quality benefits. Limited studies show that losses of total $\mathrm{N}$, total phosphorus $(\mathrm{P})$, dissolved $\mathrm{P}$, and sediment in surface runoff and subsurface discharge may also be reduced by rotating corn with legumes (tables A4 through A7 in the Appendix). For example, King et al. (2016) found that, during the soybean years in a corn-soybean rotation, total $\mathrm{N}$ and dissolved $\mathrm{P}$ losses in subsurface drainage discharge were reduced by an average of $7 \%$ and $14 \%$, respectively, compared to corn years, while total P lost was about the same between corn and soybean years. Similarly, Shipitalo et al. (2013) measured a reduction of dissolved $\mathrm{P}$ and total $\mathrm{P}$ losses in runoff in soybean years by $55 \%$ and $43 \%$, respectively, compared to corn years in a cornsoybean rotation; average sediment losses were about the same or more for soybean compared to corn. Pease et al. (2018), in an extensive edge-of-field network study, found that total $\mathrm{P}$ and dissolved $\mathrm{P}$ losses in runoff and subsurface discharge were generally higher for continuous corn and lower for corn-soybean and corn-soybean-wheat rotations, except in the case of dissolved $\mathrm{P}$ in runoff, where the average loss was highest for corn-soybean. We were unable to find many studies on nutrient and sediment losses from extended rotations. More research is needed in this area.

Including legume crops in rotation systems, particularly perennial varieties, can reduce nutrient losses from agricultural fields. Crop rotations have the potential to improve water quality by taking up and immobilizing nitrate that would otherwise be lost to leaching or runoff and by reducing the overall amount of $\mathrm{N}$ fertilizer that must be applied over the whole rotation period. In addition to the potential $\mathrm{N}$ contribution from legumes to following crops, the effects of this agricultural conservation practice on water quality should be considered when planning and implementing legume-corn crop rotation systems.

\section{COST-EFFECTIVENESS AND WATER QUALITY IMPROVEMENTS \\ Crop Rotation Cost ANALYSIS}

The different factors that influence whether landowners and operators may adopt alternative crop rotation systems, as well as which system they decide to implement, are numerous and complex (Baumgart-Getz et al., 2012; Hoag et al., 2012; Liu et al., 2018). Technical assistance and education on nutrient management practices provided by state and government programs can aid farmers in the process of implementing these practices and encourage them to do so (Baumgart-Getz et al., 2012; Hoag et al., 2012; UCS, 2017). However, overall, system profitability is one of the major factors influencing a producer's decision to adopt a certain management practice, especially in situations where subsidies, tax breaks, and cost-sharing programs are limited (Baumgart-Getz et al., 2012; Hoag et al., 2012; McComb et al., 1988). Public and private programs such as these can increase the profitability of nutrient management approaches, encouraging landowners and operators to adopt such practices, especially if the crops chosen for a rotation may not independently generate as much revenue as continuous corn (Baumgart-Getz et al., 2012; Higgs et al., 1990; Hoag et al., 2012; Liu et al., 2018; McComb et al., 1988; UCS, 2017).

A simple cost analysis was performed as part of this literature review to evaluate the relative costs associated with the implementation of extended legume-corn crop rotations compared to conventional cropping systems. For simplicity, and to align with available information, a per hectare cost was developed for a hypothetical field located within the state of Iowa, alfalfa production with a single cutting each year was assumed, and conservation tillage practices (tandem disk tilling once per season for annual crops). Iowa was chosen as the example location for this exercise because of the prevalence of continuous corn and corn-soybean rotations (Mine et al., 2014; ISU, 2019a), the state's relative impact on water quality in the upper Mississippi River basin (Jones et al., 2018), and the availability of cost information through Iowa State University's “Ag Decision Maker" Farm Custom Rate Survey (ISU, 2019b).

We included the following practical benefits of legume rotation effects in our cost analysis: appropriate $\mathrm{N}$ fertilizer application rates estimated for each crop based on economic return and legume $\mathrm{N}$ contributions, a percentage increase in corn yields following legumes, and a percentage reduction in pesticide costs for extended rotations. These parameters were included in our analysis because they account for some of the important processes associated with crop rotation systems. Our methods did not take into account tax benefit programs, government subsidies, or projected inflation, and we did not attempt to quantify other benefits associated with extended crop rotations, such as reductions in the farm's carbon footprint or nitrous oxide emissions, or the value of improvements in water quality and environmental services. While these are also important factors to consider when evaluating crop rotations, the latter were not as well studied and incorporate more complex processes than could be represented in this simple cost analysis.

The conventional cropping systems that were considered in this cost analysis included continuous monoculture corn (CC) and a two-year annual corn-soybean rotation (CS), as these are the most prevalent cropping systems in the U.S. Corn Belt (USDA-NASS, 2010; Mine et al., 2014; ISU, 2019a). The extended crop rotation systems we evaluated were a five-year corn (Zea mays [L.])-soybean (Glycine max 
[L.] Merr.)-alfalfa (Medicago sativa [L.])-alfalfa-alfalfa rotation (CSAAA), a five-year corn-oat (Avena sativa [L.])-alfalfa-alfalfa-alfalfa rotation (COAAA), a three-year cornsoybean-wheat (Triticum aestivum [L.]) rotation (CSW), and a six-year alfalfa-alfalfa-alfalfa-corn-soybean-oat rotation (AAACSO). We also evaluated the relative costs of a continuous alfalfa cropping system for comparison purposes.

Relevant values for costs, prices, yields, and other inputs were gathered from the USDA-NASS and the Iowa State University Cooperative Extension Service. Additionally, pesticide costs and the wheat seeding rate were sourced from the University of Illinois, the cost of soybean seeds was sourced from Michigan State University, and the recommended $\mathrm{N}$ fertilizer rate for oats and wheat came from the University of Minnesota. The use of input information from other nearby states to supplement those specifically for the state of Iowa was based on the availability of data and the location of these states within the region of interest. More details on the inputs and calculations can be found in the Supplemental Material (available at https://doi.org/10.13031/13924703.v1).

Estimated total present costs for individual crops in each rotation over the course of a 10 -year period were subtracted from estimated gross revenues, resulting in an overall net revenue value for each cropping system. While our calculations relied on current statistics for costs, prices, and yields for the U.S., with some specifically for the state of Iowa, the methods used could be tailored to any location or management scenario with appropriate inputs and serve as a useful tool for assessing relative cost benefits for various crop rotation systems or other agricultural conservation practices.

The results of our analysis showed that costs for $\mathrm{N}$ fertilizer and pesticides were reduced in extended rotations, and revenue from corn was slightly increased due to the positive effects of legume rotations on corn grain yield (in the Supplemental Material). Our estimated annualized net revenue was greatest for the corn-soybean rotation, followed by the continuous corn and corn-soybean-wheat cropping systems, whereas the extended rotations and continuous alfalfa were the least profitable (table 1). Our findings are similar to those from some other studies on the cost benefits of legume-corn and low-input extended crop rotation systems (De Haan et al., 2017; Higgs et al., 1987; ISU, 2017; McComb et al., 1988; Schlegel et al., 2016), which found that continuous corn and corn-soybean were the most profitable cropping systems compared to extended legume-corn rotations. However, this will necessarily depend on the location and the as- sumptions made regarding input prices and revenues from crop sales. Both Liebman et al. (2008) and De Haan et al. (2017) found that the cost benefits of extended rotations and low-external-input systems could be even more profitable than traditional cropping systems in certain scenarios.

Numerous studies have been done to determine the profitability of legume-corn crop rotation systems (e.g., De Haan et al., 2017; Liebman et al., 2008; Lötjönen and Ollikainen, 2017; Mallarino et al., 2005). Producers generally want to increase farm revenues, which means that rotating corn with a crop that is not marketable, and/or a crop that takes up time during which more profitable crops could be grown, is less appealing from an agronomic standpoint. In general, growing continuous corn and growing corn with soybeans or other grain legumes that can be harvested and sold tend to be the most profitable rotation systems based solely on gross yield profits (De Haan et al., 2017; Higgs et al., 1987; McComb et al., 1988; Schlegel et al., 2016). However, when savings on nitrate fertilizer and environmental benefits are factored in, crop rotations including alfalfa and other forage legumes often come out ahead (De Haan et al., 2017; Goplen et al., 2018; McComb et al., 1988; Stanger and Lauer, 2008).

The profitability of one legume-corn crop rotation system over another will depend on current markets and the feasibility of growing a certain crop in a given location. This variability is influenced by factors such as local climate, soil physical and chemical characteristics, the other agricultural management practices in place, current fertilizer costs, and current crop prices. One major barrier for farmers in the adoption of extended crop rotation systems is the large upfront costs associated with investing in more varied machinery to cultivate a more diversified crop (Higgs et al., 1990; Reeves, 1994; UCS, 2017). Overall, though, rotating crops with legumes can reduce the variability in profits year to year, as well as increase yields of subsequent crops, thereby reducing potential risk (Bullock, 1992; Lötjönen and Ollikainen, 2017; Mallarino et al., 2005; UCS, 2017). Additionally, including winter legume cover crops in a rotation system may further reduce $\mathrm{N}$ fertilizer costs due to their $\mathrm{N}$ contribution to following crops (Gentry et al., 2013b; Yang et al., 2019), although seeding would incur its own costs, and the cover crops may not be marketable if the system does not include pasture-raised livestock. Ultimately, economic considerations must be made when choosing the type of legume crop and rotation sequence to provide the best possible conservation benefits at a reasonable cost.

Table 1. Summary of equal annualized net revenues (in dollars per hectare per year), calculated over 10 years, and mean annual subsurface nitrate loss calculated from the literature data for each cropping system (fig. 3). Cost analysis results are based on costs and statistics for Iowa or similar states in the U.S. Corn Belt. C = corn (Zea mays [L.]), S = soybean (Glycine max [L.] Merr.), A = alfalfa (Medicago sativa [L.]), W= winter wheat (Triticum aestivum $[\mathrm{L}$.$] ), \mathrm{O}=$ oat (Avena sativa [L.]). The number of studies for each mean nitrate loss value is shown in parentheses.

\begin{tabular}{cccc}
\hline Cropping System & Definition & $\begin{array}{c}\text { Net Revenue } \\
\left(\$ \text { ha }^{-1} \text { year }\right.\end{array}$ & $\begin{array}{c}\text { Mean Subsurface } \mathrm{NO}_{3} \text { Loss } \\
\left(\mathrm{kg} \mathrm{N} \mathrm{h}^{-1} \text { year }\right.\end{array}$ \\
\hline CS & Corn-soybean & 141.83 & $32.4(16)$ \\
CC & Continuous corn & 81.74 & $31.3(12)$ \\
CSW & Corn-soybean-wheat & 36.00 & $12.2(1)$ \\
AAACSO & Alfalfa-alfalfa-alfalfa-corn-soybean-oat & 8.24 & $11.8(1)$ \\
CSAAA & Corn-soybean-alfalfa-alfalfa-alfalfa & -80.51 & - \\
COAAA & Corn-oat-alfalfa-alfalfa-alfalfa & -99.97 & $13.4^{[a]}(2)$ \\
A & Continuous alfalfa & -202.66 & $22.3(4)$ \\
\hline
\end{tabular}

[a] Mean annual nitrate loss for COAA rotation. 


\section{WATER QUALITY AND COST-EFFECTIVENESS}

To address the main objectives of this literature review, we attempted to integrate our cost analysis results with water quality data from the literature. It is crucial to consider all costs, benefits, and environmental effects when planning and implementing agricultural conservation practices to minimize the environmental impacts while optimizing the agronomic benefits for the producer, thereby encouraging more widespread adoption. Here, we synthesize the results of our literature search on the effects of crop rotations on water quality, specifically for subsurface nitrate losses, with the results of our cost analysis accounting for the agronomic rotation benefits of legumes.

Based on overall means from the literature data, it appears that the combined agronomic and water quality benefits are greatest for the conventional corn-soybean rotation (table 1). Corn-soybean was more cost-effective than continuous corn in terms of our estimated annual per hectare net revenue, while the average annual per hectare nitrate loss was about the same as continuous corn (32.4 vs. $31.3 \mathrm{~kg} \mathrm{~N} \mathrm{ha}^{-1}$ year $\left.^{-1}\right)$. One-way ANOVA showed that the means were not significantly different $(\mathrm{F}(1,121)=0.0474, \mathrm{p}=0.828)$. Although the subsurface nitrate loss from the AAACSO extended rotation was the lowest among the cropping systems evaluated here, it had a much lower net revenue compared to either continuous corn or corn-soybean. Yet the AAACSO rotation was still more profitable than continuous alfalfa or the CSW rotation. It should be noted that the extended rotation CSAAA from our cost analysis could not be found in the literature, although it has been proposed as a viable alternative crop rotation system (ISU, 2017). In addition, some of the mean nitrate losses (i.e., for the AAACSO, COAAA, and CSW rotations) were calculated from a smaller number of research articles than the conventional CS rotation. Therefore, it is difficult to compare the water quality implications across all crop rotations mentioned here, and this comparison may not be definitive. More research is needed on the water quality implications of extended rotations to provide a larger data pool from which more definitive conclusions can be drawn.

Using data from reviewed studies that directly compared the nitrate- $\mathrm{N}$ load reductions of different crop rotations with respect to a conventional baseline (continuous corn), we found that the mean nitrate- $\mathrm{N}$ loss from corn-soybean was much lower than that from continuous corn (table 2). Meanwhile, the net revenue calculated for corn-soybean from our cost analysis was much higher than the net revenue for continuous corn (table 1). From these data, we calculated a costeffectiveness value, in $\$$ per kg nitrate-N load reduction, using the difference between corn-soybean net revenue and continuous corn net revenue from the cost analysis, and then divided by the difference between the mean subsurface nitrate-N losses from only studies that directly compared the cropping systems. This calculation produced a negative "cost" value, which means that revenue is increased while nitrate-N loss is reduced when switching from continuous corn to corn-soybean. In other words, corn-soybean yielded a net benefit (not cost) of nitrate- $\mathrm{N}$ load reduction, at $\$ 5$ per $\mathrm{kg} \mathrm{N}$ (table 2). We did not find any studies that directly compared extended crop rotations, so only the comparison between corn-soybean and continuous corn is included here.

There will necessarily be trade-offs between cost-effectiveness and potential environmental impacts for a given crop rotation system or any agricultural conservation practice. More research is needed, especially on extended crop rotations, to form a more comprehensive understanding of these trade-offs so that appropriate recommendations can be made.

\section{MONITORING RECOMMENDATIONS}

Various methods were employed in the studies reviewed to monitor the effectiveness of crop rotation systems. In those studies that evaluated the effects of legumes on subsequent corn yields and $\mathrm{N}$ response, $\mathrm{N}$ fertilizer application rate levels were carefully chosen. In addition, corn grain, stover left in the field after grain harvesting, and/or dry matter yields were often measured, and plant samples were analyzed for each crop rotation treatment under study. For future $\mathrm{N}$ response studies, it is recommended that multiple (more than five) increments of $\mathrm{N}$ fertilizer application rate levels be included to provide more data points for analysis and more precisely capture the effects of preceding legumes on subsequent crop yields. It would also be informative to include more than one type of legume in future studies to compare rotation benefits among different crops under similar conditions. Including easily measurable legume growth parameters, such as crop canopy height and residue cover (Kuo and Jellum, 2002), would also provide more data on the effects of other management practices on legume $\mathrm{N}$ credits.

In studies that evaluated the effects of legumes on water quality, nutrient concentrations and the amount of subsurface drainage discharge, leachate, or surface runoff were measured for each treatment using different analytical approaches, and loss metrics were determined for the water quality parameters under study. Some studies we found in the literature search employed a modeling or paired watershed approach to estimate the effects of crop rotation systems on water quality (e.g., Puntel et al. 2016), which may be more feasible than edge-of-field monitoring for multiple farms and fields. However, the results from modeling and paired watershed studies were not included in the data pool for this article because our scope was limited to empirical field data.

Regardless of the specific techniques used for a given experiment, authors presenting results for crop rotation water quality studies should consider including quantification (i.e.,

Table 2. Results of cost-effectiveness analysis for corn-soybean with respect to the conventional baseline (continuous corn). Numbers in parentheses indicate the number of studies that directly compared the cropping systems listed.

\begin{tabular}{|c|c|c|c|c|c|}
\hline Cropping System & Definition & $\begin{array}{l}\text { Net Revenue } \\
\left(\$ \text { ha }^{-1} \text { year }^{-1}\right)\end{array}$ & $\begin{array}{c}\text { Mean Subsurface } \\
\mathrm{NO}_{3} \text { Load } \\
\left(\mathrm{kg} \mathrm{N} \mathrm{ha}^{-1} \text { year-1 }\right)\end{array}$ & $\begin{array}{c}\text { Percent } \mathrm{NO}_{3} \text { Load } \\
\text { Reduction } \\
(\%) \\
\end{array}$ & $\begin{array}{l}\text { Cost Benefit of } \mathrm{NO}_{3} \\
\text { Load Reduction } \\
\left(\$ \mathrm{~kg} \mathrm{~N}^{-1}\right)\end{array}$ \\
\hline $\mathrm{CC}$ & Continuous corn & 81.74 & $22.0(7)$ & - & - \\
\hline $\mathrm{CS}$ & Corn-soybean & 141.83 & $9.91(7)$ & 32.7 & 5 \\
\hline
\end{tabular}


water volume, $\mathrm{N}$ concentration, and $\mathrm{N}$ load) of loss pathways, including subsurface drainage, leaching, and/or surface runoff. They should compare experimental treatments to a control that is considered conventional, which would likely be a corn-soybean rotation. It would also be informative to include more extended crop rotations, such as those with multiple years of perennial legumes, in such water quality studies. Including detailed information about these loss pathways would allow a more complete evaluation of the impact of conservation crop rotations on water quality.

\section{SUMMARY AND CONCLUSIONS}

Adjusting the rate at which $\mathrm{N}$ fertilizer is applied to agricultural fields is one way to practice nutrient management. The rate of $\mathrm{N}$ fertilizer that must be applied to corn crops depends on the agricultural conditions in which they are grown. Fertilizer $\mathrm{N}$ that is applied to fields above what the corn crops require can be lost by leaching, discharge via subsurface drainage systems, surface runoff, or other processes, contaminating nearby water resources and leading to the eutrophication of water bodies and degradation of water quality. Fertilizer $\mathrm{N}$ application rate recommendations can be adjusted for these agricultural conditions to provide a more appropriate application rate suited to the crop's needs and growing conditions. These adjustments may account for the use of crop rotation as a conservation practice, with one beneficial crop rotation strategy being legume-corn systems. The $\mathrm{N}$ credit that is applied to recommendations for corn in rotation with legume crops can depend on various growing conditions, not least of all being which legumes are chosen for the rotation sequence. These $\mathrm{N}$ credits, while sometimes difficult to estimate for a particular agricultural system, are important to include in some form to address crop nutrient requirements while reducing the amount of nitrate pollution in agricultural watersheds.

The results from the studies and LGU publications evaluated in this review showed that there is much variability in the reported values for legume $\mathrm{N}$ credits. Even so, we found that the empirical values were very similar to the LGU recommended values across similar study locations, and overall median values were similar between the empirical studies and extension publications within soybean and alfalfa $\mathrm{N}$ credit datasets (fig. 2). Median soybean $\mathrm{N}$ credits were 43 and $34 \mathrm{~kg} \mathrm{~N} \mathrm{ha}^{-1}$ for the experimental data $(n=120)$ and the LGU recommendations $(n=30)$, respectively, and median alfalfa $\mathrm{N}$ credits were $85(n=32)$ and $90(n=77) \mathrm{kg} \mathrm{N} \mathrm{ha}^{-1}$, respectively, although it is likely that some of the LGU values could have been partly based on the results of one or more of the studies included in the analysis.

In addition to the $\mathrm{N}$ contribution to succeeding crops, legumes can provide many other benefits when included in extended crop rotation systems. For example, by improving soil texture and organic matter content (Havlin et al., 1990; Karlen et al., 2006; Lal et al., 1994; N'Dayegamiye et al., 2015), legumes can increase the efficiency with which $\mathrm{N}$ is used by other crops in the rotation. Most importantly, a reduced need to apply fertilizer $\mathrm{N}$ over the course of the legume-corn crop rotation sequence, combined with the low
$\mathrm{C}: \mathrm{N}$ ratio of legume residues, means that legumes can substantially prevent off-site migration of nitrate into nearby water resources (ISU, 2017). Because nitrate leaching losses have been found to primarily occur during the off-season between fall and spring, even more nitrate loss reductions may be realized by including cover crops, including legumes, in extended rotations (Strock et al., 2004; Askegaard et al., 2011; De Notaris et al., 2018; Abdalla et al., 2019).

Rotating corn with legumes in an extended rotation system can increase yields, save on fertilizer and pesticide costs, and reduce overall risk compared to conventional cropping systems. The profitability of crop rotation systems depends partly on how well-suited a crop is to a certain location, which is influenced by factors such as local climate, soil physical and chemical characteristics, the other agricultural management practices that are in place, and current fertilizer costs. Profitability will also depend on current agricultural markets because it may be more difficult to find markets for non-standard crops in a given area. Additionally, producers may be less likely to include these non-standard crops in a rotation if they take up time during which more marketable crops could be grown. While relatively large initial costs are associated with establishing a more diversified crop, rotating corn with legumes in an extended rotation system can be profitable, especially in production systems that are eligible for subsidies or other government assistance programs. Even though economic considerations are just one factor in the process of agricultural decision making, the total cost involved in agricultural conservation practices is one of the most important factors to producers when they are evaluating which practices to implement. The cost analysis methods used in this review could be tailored to any location or management scenario with appropriate inputs and serve as a useful tool for assessing the relative cost benefits for other agricultural conservation practices.

In sum, crop rotations must be chosen with care. The success of legume-corn crop rotations as a method for reducing the amount of nitrate lost to the environment will depend on the given soil and climatic conditions, as well as the other agricultural management practices in place. While crop rotations potentially carry many environmental benefits, even more could be realized through the implementation of integrated management strategies that include multiple conservation practices. Employing multiple conservation practices that work in tandem has the potential to be even more effective at reducing nitrate losses than any stand-alone practice, but more research is needed in this area. The information contained in this review can aid in the selection of conservation practices in corn cropping systems and help reduce agricultural nitrate pollution of water resources.

\section{ACKNOWLEDGEMENTS}

This project was supported in part by an appointment to the Research Participation Program at the U.S. Environmental Protection Agency (USEPA) Office of Research and Development (ORD), administered by the Oak Ridge Institute for Science and Education (ORISE), through an interagency agreement between the USEPA and the U.S. Department of Energy (USDOE). Although this article has been reviewed 
and approved for publication by the USEPA, the views expressed in this article are those of the authors and do not necessarily represent the views or policies of the USEPA or ORISE. The authors would like to thank Dr. Brent Johnson from USEPA, the journal editors, and the anonymous reviewers for their technical review and valuable comments and suggestions, which helped improve the manuscript.

\section{REFERENCES}

Abdalla, M., Hastings, A., Cheng, K., Yue, Q., Chadwick, D., Espenberg, M., ... Smith, P. (2019). A critical review of the impacts of cover crops on nitrogen leaching, net greenhouse gas balance, and crop productivity. Global Change Biol., 25(8), 2530-2543. https://doi.org/10.1111/gcb.14644

Alley, M. M., Martz Jr., M. E., Davis, P. H., \& Hammons, J. L. (2009). Nitrogen and phosphorus fertilization of corn. Publication 424-027. Blacksburg, VA: Virginia Cooperative Extension.

Alvey, S., Yang, C.-H., Buerkert, A., \& Crowley, D. E. (2003). Cereal/legume rotation effects on rhizosphere bacterial community structure in West African soils. Biol. Fertil. Soils, 37, 73-82. https://doi.org/10.1007/s00374-002-0573-2

Ashworth, A. J., Allen, F. L., Saxton, A. M., \& Tyler, D. D. (2016). Long-term corn yield impacted by cropping rotations and biocovers under no-tillage. Crop Econ. Prod. Mgmt., 108(4), 1-8. https://doi.org/10.2134/agronj2015.0453

Askegaard, M., Olesen, J. E., Rasmussen, I. A., \& Kristensen, K. (2011). Nitrate leaching from organic arable crop rotations is mostly determined by autumn field management. Agric. Ecosyst. Environ., 142, 149-160. https://doi.org/10.1016/j.agee.2011.04.014

Attia, A., Shapiro, C., Kranz, W., Mamo, M., \& Mainz, M. (2015). Improved yield and nitrogen use efficiency of corn following soybean in irrigated sandy loams. SSSA J., 79, 1693-1703. https://doi.org/10.2136/sssaj2015.05.0200

Bagayoko, M., Buerkert, A., Lung, G., Bationo, A., \& Römheld, V. (2000). Cereal/legume rotation effects on cereal growth in Sudano-Sahelian West Africa: Soil mineral nitrogen, mycorrhizae, and nematodes. Plant Soil, 218, 103-116. https://doi.org/10.1023/A:1014957605852

Bakhsh, A., Kanwar, R. S., Pederson, C., \& Bailey, T. B. (2007). Nsource effects on temporal distribution of $\mathrm{NO}_{3}-\mathrm{N}$ leaching losses to subsurface drainage water. Water Air Soil Pollut., 181(1-4), 35-50. https://doi.org/10.1007/s11270-006-9274-z

Baumgart-Getz, A., Prokopy, L. S., \& Floress, K. (2012). Why farmers adopt best management practice in the United States: A meta-analysis of the adoption literature. J. Environ. Mgmt., 96(1), 17-25. https://doi.org/10.1016/j.jenvman.2011.10.006

Baumhardt, R. L., \& Anderson, R. L. (2006). Crop choices and rotation principles. In Dryland agriculture (2nd Ed., pp. 113139). Madison, WI: ASA, CSSA, SSSA.

Beegle, D. B. (2015). Nitrogen (N) management. In The Penn State agronomy guide 2015-2016. University Park, PA: Pennsylvania State University.

Blesh, J., \& Drinkwater, L. E. (2013). The impact of nitrogen source and crop rotation on nitrogen mass balances in the Mississippi River basin. Ecol. Appl., 23(5), 1017-1035. https://doi.org/10.1890/12-0132.1

Bloem, A. A., \& Barnard, R. O. (2001). Effect of annual legumes on soil nitrogen and on the subsequent yield of maize and grain sorghum. South African J. Plant Soil, 18(2), 56-61. https://doi.org/10.1080/02571862.2001.10634404

Bullock, D. G. (1992). Crop rotation. Crit. Rev. Plant Sci., 11(4), 309-326. https://doi.org/10.1080/07352689209382349
Bundy, L. G., Andraski, T. W., \& Wolkowski, R. P. (1993). Nitrogen credits in soybean-corn crop sequences on three soils. Agron. J., 85(5), 1061-1067.

https://doi.org/10.2134/agronj1993.00021962008500050020x

Cassman, K. G., Dobermann, A., \& Walters, D. T. (2002). Agrosystems, nitrogen use efficiency, and nitrogen management. Ambio, 31, 132-140. https://doi.org/10.1579/0044-744731.2.132

Coulter, J. A., \& Nafziger, E. D. (2008). Continuous corn response to residue management and nitrogen fertilization. Agron. J., 100(6), 1774-1780. https://doi.org/10.2134/agronj2008.0170

Crookston, R. K., \& Kurle, J. E. (1989). Corn residue effect on the yield of corn and soybean grown in rotation. Agron. J., 81(2), 229-232.

https://doi.org/10.2134/agronj1989.00021962008100020018x

Crookston, R. K., Kurle, J. E., Copeland, P. J., Ford, J. H., \& Lueschen, W. E. (1991). Rotational cropping sequence affects yield of corn and soybean. Agron. J., 83(1), 108-113. https://doi.org/10.2134/agronj1991.00021962008300010026x

Daryanto, S., Wang, L., \& Jacinthe, P.-A. (2017). Impacts of notillage management on nitrate loss from corn, soybean, and wheat cultivation: A meta-analysis. Nature: Sci. Rep., 7(1), 1-9. https://doi.org/10.1038/s41598-017-12383-7

David, M. B., Drinkwater, L. E., \& McIsaac, G. F. (2010). Sources of nitrate yields in the Mississippi River basin. J. Environ. Qual., 39(5), 1657-1667. https://doi.org/10.2134/jeq2010.0115

De Haan, R. L., Schuiteman, M. A., \& Vos, R. J. (2017). Residual soil nitrate content and profitability of five cropping systems in northwest Iowa. PLoS One, 12(3), e0171994. https://doi.org/10.1371/journal.pone.0171994

De Notaris, C., Rasmussen, J., Sørensen, P., \& Olesen, J. E. (2018). Nitrogen leaching: A crop rotation perspective on the effect of $\mathrm{N}$ surplus, field management, and use of catch crops. Agric. Ecosyst. Environ., 255, 1-11. https://doi.org/10.1016/j.agee.2017.12.009

Drinkwater, L. E., Janke, R. R., \& Rossoni-Longnecker, L. (2000). Effects of tillage intensity on nitrogen dynamics and productivity in legume-based grain systems. Plant Soil, 227(12), 99-113. https://doi.org/10.1023/A:1026569715168

Drinkwater, L. E., Wagoner, P., \& Sarrantonio, M. (1998). Legumebased cropping systems have reduced carbon and nitrogen losses. Nature, 396(6708), 262-265. https://doi.org/10.1038/24376

El-Hout, N. M., \& Blackmer, A. M. (1990). Nitrogen status of corn after alfalfa in 29 Iowa fields. J. Soil Water Cons., 45(1), 115117.

Ennin, S. A., Dapaah, H. K., \& Abaidoo, R. C. (2004). Nitrogen credits from cowpea, soybean, groundnut, and mucuna to maize in rotation. West African J. Appl. Ecol., 6(1). https://doi.org/10.4314/wajae.v6i1.45610

Fox, R. H., Zhu, Y., Toth, J. D., Jemison, J. M., \& Jabro, J. D. (2001). Nitrogen fertilizer rate and crop management effects on nitrate leaching from an agricultural field in central Pennsylvania. Sci. World, 1, 181-186. https://doi.org/10.1100/tsw.2001.91

Francis, D. D., \& Schepers, J. S. (1989). Soil nitrate concentrations as influenced by nitrogen fertilizer, mineralization, and crop uptake. In Agronomy abstracts. Madison, WI: ASA.

Frankenberger, W. T., \& Abdelmagid, H. M. (1985). Kinetic parameters of nitrogen mineralization rates of leguminous crops incorporated into soil. Plant Soil, 87(2), 257-271. https://doi.org/10.1007/BF02181865

Gentry, L. E., Below, F. E., David, M. B., \& Bergerou, J. A. (2001). Source of the soybean N credit in maize production. Plant Soil, 236(2), 175-184. https://doi.org/10.1023/A:1012707617126 
Gentry, L. E., Snapp, S. S., Price, R. F., \& Gentry, L. F. (2013b). Apparent red clover nitrogen credit to corn: Evaluating cover crop introduction. Agron. J., 105(6), 1658-1664. https://doi.org/10.2134/agronj2013.0089

Gentry, L. F., Ruffo, M. L., \& Below, F. E. (2013a). Identifying factors controlling the continuous corn yield penalty. Agron. J., 105(2), 295-303. https://doi.org/10.2134/agronj2012.0246

Goplen, J. J., Coulter, J. A., Sheaffer, C. C., Becker, R. L., Breitenbach, F. R., Behnken, L. M., \& Gunsolus, J. L. (2018). Economic performance of crop rotations in the presence of herbicide-resistant giant ragweed. Agron. J., 110(1), 260-268. https://doi.org/10.2134/agronj2016.09.0536

Grantham, A. (2015). Improving nitrogen management in agriculture: Opportunities gleaned from organic systems. University Park, PA: Pennsylvania State University.

Green, T. R., Kipka, H., David, O., \& McMaster, G. S. (2018). Where is the USA Corn Belt, and how is it changing? Sci. Total Environ., 618, 1613-1618. https://doi.org/10.1016/j.scitotenv.2017.09.325

Harris, G. H., \& Hesterman, O. B. (1990). Quantifying the nitrogen contribution from alfalfa to soil and two succeeding crops using nitrogen-15. Agron. J., 82(1), 129-134. https://doi.org/10.2134/agronj1990.00021962008200010028x

Havlin, J. L., Kissel, D. E., Maddux, L. D., Claasen, M. M., \& Long, J. H. (1990). Crop rotation and tillage effects on soil carbon and nitrogen. SSSA J., 54, 448-452. https://doi.org/10.2136/sssaj1990.03615995005400020026x

Havlin, J. L., Tisdale, S. L., Nelson, W. L., \& Beaton, J. D. (2014). Soil fertility and fertilizers: An introduction to nutrient management (8th Ed.). Upper Saddle River, NJ: Pearson.

Heichel, G. H. (1987a). Legume nitrogen: Symbiotic fixation and recovery by subsequent crops. In Energy in world agriculture handbook (Vol. 2, pp. 63-80). Amsterdam, The Netherlands: Elsevier Science.

Heichel, G. H. (1987b). Legumes as a source of nitrogen in conservation tillage systems. In J. F. Power (Ed.), The role of legumes in conservation tillage systems (pp. 29-37). Madison, WI: SSSA.

Hesterman, O. B., Russelle, M. P., Sheaffer, C. C., \& Heichel, G. H. (1987). Nitrogen utilization from fertilizer and legume residues in legume-corn rotations. Agron. J., 79(4), 726-731. https://doi.org/10.2134/agronj1987.00021962007900040029x

Hesterman, O. B., Sheaffer, C. C., Barnes, D. K., Lueschen, W. E., \& Ford, J. H. (1986). Alfalfa dry matter and nitrogen production, and fertilizer nitrogen response in legume-corn rotations. Agron. J., 78(1), 19-23. https://doi.org/10.2134/agronj1986.00021962007800010005x

Higgs, R. L., Ambrosius, J., Peterson, A., Klemme, R., Paulson, W. H., \& McComb, S. R. (1987). Economic returns for six longterm rotations in the upper Mississippi Valley. Proc. 42nd Annual Meeting of Soil Conservation Society of America.

Higgs, R. L., Peterson, A. E., \& Paulson, W. H. (1990). Crop rotations sustainable and profitable. J. Soil Water Cons., 45(1), 68-70.

Hoag, D., Luloff, A., \& Osmond, D. (2012). Socio-economic analysis from the NIFA-CEAP projects. In D. Osmond, D. Meals, D. Hoag, \& M. Arabi (Eds.), How to build better agricultural conservation programs to protect water quality: The NIFA-CEAP experience. Ankeny, IA: Soil and Water Conservation Society.

ISU. (2017). Iowa nutrient reduction strategy. Ames, IA: Iowa State University. Retrieved from http://www.nutrientstrategy.iastate.edu/

ISU. (2019a). Iowa farm and rural life poll: 2018 Summary report (SOC 3090). Ames, IA: Iowa State University Extension and Outreach. Retrieved from
https://store.extension.iastate.edu/product/Iowa-Farm-and-RuralLife-Poll-2018-Summary-Report

ISU. (2019b). 2019 Iowa farm custom rate survey (File A3-10). Ames, IA: Iowa State University. Retrieved from https://www.extension.iastate.edu/agdm/crops/html/a3-10.html

Jones, C. S., Nielsen, J. K., Schilling, K. E., \& Weber, L. J. (2018). Iowa stream nitrate and the Gulf of Mexico. PLoS One, 13(4), e0195930. https://doi.org/10.1371/journal.pone.0195930

Kanwar, R. S., Colvin, T. S., \& Karlen, D. L. (1997). Ridge, moldboard, chisel, and no-till effects on tile water quality beneath two cropping systems. J. Prod. Agric., 10(2), 227-234.

Kanwar, R. S., Cruse, R. M., Ghaffarzadeh, M., Bakhsh, A., Karlen, D. L., \& Bailey, T. B. (2005). Corn-soybean and alternative cropping systems effects on $\mathrm{NO}_{3}-\mathrm{N}$ leaching losses in subsurface drainage water. Appl. Eng. Agric., 21(2), 181-188. https://doi.org/10.13031/2013.18151

Karlen, D. L., Hurley, E. G., Andrews, S. S., Cambardella, C. A., Meek, D. W., Duffy, M. D., \& Mallarino, A. P. (2006). Crop rotation effects on soil quality at three northern corn/soybean belt locations. Agron. J., 98(3), 484-495. https://doi.org/10.2134/agronj2005.0098

Kelner, D. J., Vessey, J. K., \& Entz, M. H. (1997). The nitrogen dynamics of 1-, 2-, and 3-year stands of alfalfa in a cropping system. Agric. Ecosyst. Environ., 64(1), 1-10. https://doi.org/10.1016/S0167-8809(97)00019-4

Ketterings, Q., Klausner, S. D., \& Czymmek, K. (2003). Nitrogen guidelines for field crops in New York. Ithaca, NY: Cornell University. Retrieved from http://cceonondaga.org/resources/nitrogen-guidelines-for-fieldcrops

King, K. W., Williams, M. R., \& Fausey, N. R. (2016). Effect of crop type and season on nutrient leaching to tile drainage under a corn-soybean rotation. J. Soil Water Cons., 71(1), 56-68. https://doi.org/10.2489/jswc.71.1.56

Kitur, B. L., Smith, M. S., Blevins, R. L., \& Frye, W. W. (1984). Fate of ${ }^{15} \mathrm{~N}$-depleted ammonium nitrate applied to no-tillage and conventional tillage corn. Agron. J., 76, 240-242. https://doi.org/10.2134/agronj1984.00021962007600020016x

Klocke, N. L., Watts, D. G., Schneekloth, J. P., Davison, D. R., Todd, R. W., \& Parkhurst, A. M. (1999). Nitrate leaching in irrigated corn and soybean in a semi-arid climate. Trans. ASAE, 42(6), 1621-1630. https://doi.org/10.13031/2013.13328

Kuo, S., \& Jellum, E. J. (2002). Influence of winter cover crop and residue management on soil nitrogen availability and corn. Agron. J., 94(3), 501-508. https://doi.org/10.2134/agronj2002.5010

Lal, R., Mahboubi, A. A., \& Fausey, N. R. (1994). Long-term tillage and rotation effects on properties of a central Ohio soil. SSSA J., 58(2), 517-522. https://doi.org/10.2136/sssaj1994.03615995005800020038x

Lawlor, P. A., Helmers, M. J., Baker, J. L., Melvin, S. W., \& Lemke, D. W. (2008). Nitrogen application rate effect on nitratenitrogen concentration and loss in subsurface drainage for a corn-soybean rotation. Trans. ASABE, 51(1), 83-94. https://doi.org/10.13031/2013.24229

Liebman, M., Gibson, L. R., Sundberg, D. N., Heggenstaller, A. H., Westerman, P. R., Chase, C. A., ... Dixon, P. M. (2008). Agronomic and economic performance characteristics of conventional and low-external-input cropping systems in the central Corn Belt. Agron. J., 100(3), 600-610. https://doi.org/10.2134/agronj2007.0222

Liu, T., Bruins, R. J., \& Heberling, M. T. (2018). Factors influencing farmers' adoption of best management practices: A review and synthesis. Sustainability, 10(2), 432. https://doi.org/10.3390/su10020432 
Lory, J. A., Russelle, M. P., \& Peterson, T. A. (1995). A comparison of two nitrogen credit methods: Traditional vs. difference. Agron. J., 87(4), 648-651. https://doi.org/10.2134/agronj1995.00021962008700040007x

Lötjönen, S., \& Ollikainen, M. (2017). Does crop rotation with legumes provide an efficient means to reduce nutrient loads and GHG emissions? Rev. Agric. Food Environ. Studies, 98(4), 283312. https://doi.org/10.1007/s41130-018-0063-z

Lund, M. G., Carter, P. R., \& Oplinger, E. S. (1993). Tillage and crop rotation affect corn, soybean, and winter wheat yields. $J$. Prod. Agric., 6(2), 207-213. https://doi.org/10.2134/jpa1993.0207

Ma, B. L., Ying, J., Dwyer, L. M., Gregorich, E. G., \& Morrison, M. J. (2003). Crop rotation and soil $\mathrm{N}$ amendment effects on maize production in eastern Canada. Canadian J. Soil Sci., 83(5), 483-495. https://doi.org/10.4141/S02-071

Mallarino, A. P., Ortiz-Torres, E., \& Pecinovsky, K. T. (2005). Effects of crop rotation and nitrogen fertilization on crop production. Ames, IA: Iowa State University. https://doi.org/10.31274/farmprogressreports-180814-138

Maloney, T. S., Silveira, K. G., \& Oplinger, E. S. (1999). Rotational vs. nitrogen-fixing influence of soybean on corn grain and silage yield and nitrogen use. J. Prod. Agric., 12(2), 175-187. https://doi.org/10.2134/jpa1999.0175

McComb, S. R., Klemme, R., \& Ambrosius, J. (1988). The effect of government programs on profit levels and variance in rotation and continuous cropping systems, 1977-1986. Proc. American Agricultural Economics Association Annual Meeting.

Meese, B. G., Carter, P. R., Oplinger, E. S., \& Pendleton, J. W. (1991). Corn/soybean rotation effect as influenced by tillage, nitrogen, and hybrid/cultivar. J. Prod. Agric., 4(1), 74-80. https://doi.org/10.2134/jpa1991.0074

Meisinger, J. J. (1984). Evaluating plant-available nitrogen in soilcrop systems. In R. D. Hauck (Ed.), Nitrogen in crop production (pp. 391-416). Madison, WI: ASA.

Mine, S., Zoubek, S., Cory-Watson, D., \& Lowe, M. (2014). Adoption of conservation agriculture: Economic incentives in the Iowa corn value chain. Durham, North Carolina: Datu Research. Retrieved from https://www.daturesearch.com/adoption-of-conservationagriculture-economic-incentives-in-the-iowa-corn-value-chain/

Morris, T. F., Murrell, T. S., Beegle, D. B., Camberato, J. J., Ferguson, R. B., Grove, J., ... McGrath, J. M. (2018). Strengths and limitations of nitrogen rate recommendations for corn and opportunities for improvement. Agron. J., 110(1), 1-37. https://doi.org/10.2134/agronj2017.02.0112

Mulvaney, M. J., Balkcom, K. S., Wood, C., \& Jordan, D. (2017). Peanut residue carbon and nitrogen mineralization under simulated conventional and conservation tillage. Agron. J., 109(2), 696-705. https://doi.org/10.2134/agronj2016.04.0190

Nafziger, E. (2012). Chapter 4: Small grains and grain sorghum. In Illinois agronomy handbook (24th Ed.). Champaign, IL: University of Illinois Crop Science Extension and Outreach. Retrieved from https://extension.cropsciences.illinois.edu/handbook/

Nafziger, E. D., Sawyer, J. E., \& Hoeft, R. G. (2004). Formulating $\mathrm{N}$ recommendations for corn in the Corn Belt using recent data. Proc. North Central Extension-Industry Soil Fertility Conf., 20 (pp. 5-11).

N'Dayegamiye, A., Whalen, J. K., Tremblay, G., Nyiraneza, J., Grenier, M., Drapeau, A., \& Bipfubusa, M. (2015). The benefits of legume crops on corn and wheat yield, nitrogen nutrition, and soil properties improvement. Agron. J., 107(5), 1653-1665. https://doi.org/10.2134/agronj14.0416

Olsen, R. J., Hensler, R. F., Attoe, O. J., Witzel, S. A., \& Peterson, L. A. (1970). Fertilizer nitrogen and crop rotation in relation to movement of nitrate nitrogen through soil profiles. SSSA J., 34(3), 448-452.

https://doi.org/10.2136/sssaj1970.03615995003400030028x

Olson, R. V. (1980). Fate of tagged nitrogen fertilizer applied to irrigated corn. SSSA J., 44(3), 514-517.

https://doi.org/10.2136/sssaj1980.03615995004400030015x

Omay, A. B., Rice, C. W., Maddux, L. D., \& Gordon, W. B. (1998). Corn yield and nitrogen uptake in monoculture and in rotation with soybean. SSSA J., 62(6), 1596-1603. https://doi.org/10.2136/sssaj1998.03615995006200060017x

Owens, L. B. (1990). Nitrate-nitrogen concentrations in percolate from lysimeters planted to a legume-grass mixture. J. Environ. Qual., 19(1), 131-135. https://doi.org/10.2134/jeq1990.00472425001900010019x

Owens, L. B., Malone, R. W., Shipitalo, M. J., Edwards, W. M., \& Bonta, J. V. (2000). Lysimeter study of nitrate leaching from a corn-soybean rotation. J. Environ. Qual., 29(2), 467-474. https://doi.org/10.2134/jeq2000.00472425002900020015x

Pease, L. A., King, K. W., Williams, M. R., LaBarge, G. A., Duncan, E. W., \& Fausey, N. R. (2018). Phosphorus export from artificially drained fields across the eastern Corn Belt. J. Great Lakes Res., 44(1), 43-53. https://doi.org/10.1016/j.jglr.2017.11.009

Peterson, T. A., \& Varvel, G. E. (1989). Crop yield as affected by rotation and nitrogen rate: III. Corn. Agron. J., 81, 735-738. https://doi.org/10.2134/agronj1989.00021962008100050007x

Piske, J. T., \& Peterson, E. W. (2020). The role of corn and soybean cultivation on nitrate export from Midwestern U.S. agricultural watersheds. Environ. Earth Sci., 79(208), 1-4. https://doi.org/10.1007/s12665-020-08964-x

Power, J. F., Doran, J. W., \& Wilhelm, W. W. (1986). Uptake of nitrogen from soil, fertilizer, and crop residues by no-till corn and soybeans. SSSA J., 50(1), 137-142. https://doi.org/10.2136/sssaj1986.03615995005000010027x

Puntel, L. A., Sawyer, J. E., Barker, D. W., Dietzel, R., Poffenbarger, H., Castellano, M. J., ... Archontoulis, S. V. (2016). Modeling long-term corn yield response to nitrogen rate and crop rotation. Front. Plant Sci., 7, 1630. https://doi.org/10.3389/fpls.2016.01630

Randall, G. W., \& Mulla, D. J. (2001). Nitrate nitrogen in surface waters as influenced by climatic conditions and agricultural practices. J. Environ. Qual., 30(2), 337-344. https://doi.org/10.2134/jeq2001.302337x

Randall, G. W., \& Sawyer, J. E. (2008). Nitrogen application timing, forms, and additives. In Final Report: Gulf hypoxia and local water quality concerns workshop (pp. 73-85). St. Joseph, MI: ASABE.

Randall, G. W., Huggins, D. R., Russelle, M. P., Fuchs, D. J., Nelson, W. W., \& Anderson, J. L. (1997). Nitrate losses through subsurface tile drainage in conservation reserve program, alfalfa, and row crop systems. J. Environ. Qual., 26(5), 1240-1247. https://doi.org/10.2134/jeq1997.00472425002600050007x

Reeves, D. W. (1994). Cover crops and rotations. In Advances in soil science: Crops residue management (pp. 125-172). Boca Raton, FL: CRC Press. https://doi.org/10.1201/97813510712467

Reid, L. M., Zhu, X., \& Ma, B. L. (2001). Crop rotation and nitrogen effects on maize susceptibility to gibberella (Fusarium graminearum) ear rot. Plant Soil, 237(1), 1-14. https://doi.org/10.1023/A:1013311703454

Reitsma, K. D., Clay, D., Carlson, G., Bly, A., \& Reicks, G. (2016). Estimating yield goals and nitrogen, phosphorus, potassium, iron, and zinc recommendations. In D. Clay, G. Carlson, S. Clay, \& E. Byamukama (Eds.), iGrow corn: Best management practices. Brookings, SD: South Dakota State University. 
Rekha, P. N., Kanwar, R. S., Nayak, A. K., Hoang, C. K., \& Pederson, C. H. (2011). Nitrate leaching to shallow groundwater systems from agricultural fields with different management practices. J. Environ. Monit., 13(9), 2550-2558. https://doi.org/10.1039/c1em10120j

Rembon, F. S., \& MacKenzie, A. F. (1997). Soybean nitrogen contribution to corn and residual nitrate under conventional tillage and no-till. Canadian J. Soil Sci., 77(4), 543-551. https://doi.org/10.4141/S96-096

Russelle, M. P., Allan, D. L., \& Gourley, C. J. (1994). Direct assessment of symbiotically fixed nitrogen in the rhizosphere of alfalfa. Plant Soil, 159(2), 233-243. https://doi.org/10.1007/BF00009286

Saad, D. A., \& Robertson, D. M. (2020). SPARROW model inputs and simulated streamflow, nutrient, and suspended-sediment loads in streams of the Midwestern United States, 2012 Base Year: USGS data release. https://doi.org/10.3133/sir20195114

Sanchez, C. A., \& Blackmer, A. M. (1988). Recovery of anhydrous ammonia-derived nitrogen- 15 during three years of corn production in Iowa. Agron. J., 80, 102-108. https://doi.org/10.2134/agronj1988.00021962008000010023x

Schepers, J. S., Varvel, G. E., \& Watts, D. G. (1995). Nitrogen and water management strategies to reduce nitrate leaching under irrigated maize. J. Contam. Hydrol., 20(3-4), 227-239. https://doi.org/10.1016/0169-7722(95)00070-4

Schlegel, A. J., Assefa, Y., Dumler, T. J., Haag, L. A., Stone, L. R., Halvorson, A. D., \& Thompson, C. R. (2016). Limited irrigation of corn-based no-till crop rotations in west central Great Plains. Agron. J., 108(3), 1132-1141. https://doi.org/10.2134/agronj2015.0536

Seifert, C.A., Roberts, M.J., \& Lobell, D.B. (2017). Continuous corn and soybean yield penalties across hundreds of thousands of fields. Agron. J., 109, 541-548. https://doi.org/10.2134/agronj2016.03.0134

Shipitalo, M. J., Owens, L. B., Bonta, J. V., \& Edwards, W. M. (2013). Effect of no-till and extended rotation on nutrient losses in surface runoff. SSSA J., 77(4), 1329-1337. https://doi.org/10.2136/sssaj2013.01.0045

Shrader, W. D., Fuller, W. A., \& Cady, F. B. (1966). Estimation of a common nitrogen response function for corn (Zea mays) in different crop rotations. Agron. J., 58(4), 397-401. https://doi.org/10.2134/agronj1966.00021962005800040010x

Singer, J. W., \& Cox, W. J. (1998). Agronomics of corn production under different crop rotations in New York. J. Prod. Agric., 11(4), 462-468. https://doi.org/10.2134/jpa1998.0462

Smith, M. S., Frye, W. W., \& Varco, J. J. (1987). Legume winter cover crops. In Advances in soil science (Vol. 7, pp. 95-139). New York, NY: Springer. https://doi.org/10.1007/978-1-46124790-6_3

Stanford, G. (1973). Rationale for optimum nitrogen fertilization in corn production. J. Environ. Qual., 2(2), 159-166. https://doi.org/10.2134/jeq1973.00472425000200020001x

Stanger, T. F., \& Lauer, J. G. (2008). Corn grain yield response to crop rotation and nitrogen over 35 years. Agron. J., 100(3), 643650. https://doi.org/10.2134/agronj2007.0280

Strock, J. S., Porter, P. M., \& Russelle, M. P. (2004). Cover cropping to reduce nitrate loss through subsurface drainage in the northern U.S. Corn Belt. J. Environ. Qual., 33(3), 10101016. https://doi.org/10.2134/jeq2004.1010

Syswerda, S. P., Basso, B., Hamilton, S. K., Tausig, J. B., \& Robertson, G. P. (2012). Long-term nitrate loss along an agricultural intensity gradient in the upper Midwest USA. Agric. Ecosyst. Environ., 149, 10-19. https://doi.org/10.1016/j.agee.2011.12.007

UCS. (2017). Rotating crops, turning profits: How diversified farming systems can help farmers while protecting soil and preventing pollution. Reports and Multimedia Report. Cambridge, MA: Union of Concerned Scientists. Retrieved from https://www.ucsusa.org/resources/rotating-crops-turning-profits

USDA-NASS. (2010). Acreage. Washington, DC: USDA National Agricultural Statistics Service. Retrieved from https://downloads.usda.library.cornell.edu/usdaesmis/files/j098zb09z/cj82k953d/ft848s76z/Acre-06-302010.pdf

USDA-NRCS. (2013). Nutrient management, Code 590. In National handbook of conservation practices. Washington, DC: USDA Natural Resources Conservation Service.

USDA-NRCS. (2015). Conservation crop rotation, Code 328. In National handbook of conservation practices. Washington, DC: USDA Natural Resources Conservation Service.

Vanotti, M. B., \& Bundy, L. G. (1995). Soybean effects on soil nitrogen availability in crop rotations. Agron. J., 87(4), 676-680. https://doi.org/10.2134/agronj1995.00021962008700040012x

Varvel, G. E., \& Peterson, T. A. (1990). Nitrogen fertilizer recovery by corn in monoculture and rotation systems. Agron. J., 82(5), 935-938. https://doi.org/10.2134/agronj1990.00021962008200050019x

Weed, D. A., \& Kanwar, R. S. (1996). Nitrate and water present in and flowing from root-zone soil. J. Environ. Qual., 25(4), 709719. https://doi.org/10.2134/jeq1996.00472425002500040010x

Wolkowski, R., Kelling, K., \& Bundy, L. (1998). Nitrogen management on sandy soils. Publication A3634. Madison, WI: University of Wisconsin Cooperative Ext.

Woodley, A. L., Drury, C. F., Reynolds, W. D., Tan, C. S., Yang, X. M., \& Oloya, T. O. (2018). Long-term cropping effects on partitioning of water flow and nitrate loss between surface runoff and tile drainage. J. Environ. Qual., 47(4), 820-829. https://doi.org/10.2134/jeq2017.07.0292

Yang, X. M., Drury, C. F., Reynolds, W. D., \& Reeb, M. D. (2019). Legume cover crops provide nitrogen to corn during a three-year transition to organic cropping. Agron. J., 111(6), 3253-3264. https://doi.org/10.2134/agronj2018.10.0652

Yost, M. A., Coulter, J. A., Russelle, M. P., Sheaffer, C. C., \& Kaiser, D. E. (2012). Alfalfa nitrogen credit to first-year corn: Potassium, regrowth, and tillage timing effects. Agron. J., 104(4), 953-962. https://doi.org/10.2134/agronj2011.0384

Yusuf, A. A., Abaidoo, R. C., Iwuafor, E. N., Olufajo, O. O., \& Sanginga, N. (2009). Rotation effects of grain legumes and fallow on maize yield, microbial biomass and chemical properties of an Alfisol in the Nigerian savanna. Agric. Ecosyst. Environ., 129(1), 325-331. https://doi.org/10.1016/j.agee.2008.10.007

Zhu, Y., \& Fox, R. H. (2003). Corn-soybean rotation effects on nitrate leaching. Agron. J., 95(4), 1028-1033. https://doi.org/10.2134/agronj2003.1028 